\section{INTRINSIC ELEMENTS ANALYSIS OF THE MOVIESCOTT PILGRIM VS. THE WORLD}

\author{
Priyo Danu Umboro \\ English Study Program, Sekolah Tinggi Bahasa Asing Pontianak \\ hellodanu12@gmail.com
}

Intrinsic

Elements,

Plot,

Character,

Setting,

Theme

040

\begin{abstract}
This study aims to find out the intrinsic elements used in the movie Scott Pilgrim vs. The World and to determine how intrinsic elements relate to each other in the movie. This study used a qualitative method in researching which data are taken from utterances, dialogues, and narrations in the form of screenshots of the movie. This study found the movie Scoilgrim vs. The World used the plot, settings, characters and theme as intrinsic elements. This study also found the intrinsic elements related to each other by the plot changes when a character was introduced. A new character when the setting of the place changed and the plot determined the theme of the movie.
\end{abstract}

Keywords: Intrinsic Elements, Plot, Character, Setting, Theme

\title{
INTRODUCTION
}

In this modern age of cinema, movies adapted from comic books are getting popular than ever. Movies like The Avengers Saga, Spider-man, Batman, and Justice League, which are taken from comic books created by Marvel Comics and DC Comics, dominate the box office every year. It made every numerous movie production houses race to create their movie adaptation from comic books. However, creating a movie adapted from comic books is not cheap because the production houses must pay for the license of the comic books at a great price. It happens especially when the comic books are from more famous publishers such as Marvel Comics, DC Comics, and Dark Horse Comics. Thus, some production houses divert their focus to creating a movie adapted from graphic novels instead.

Graphic novels are a form of literature that is gaining popularity these past years. Graphic novels, similar to comic books, are a mix of arts and literature. They use pictures to help tell the story, instead of just only words like other literature. Though graphic

SPECTRAL

Jurnal Ilmiah STBA Vol.7 No.1 Januari 2021 ISSN 0216-3381 novels look similar to comic books, graphic novels use more profanity than comic books, because initially graphic novels are created towards mature audiences. Graphic novels 


\section{Intrinsic}

Elements,

Plot,

Character,

Setting,

Theme

also have a darker tone compared to comic books. Graphic novels usually are standalone series, in contrast to collections or compilations of story arcs used in most comic books.

One of the graphic novels that was brought to the silver screen is Scott Pilgrim. Unlike other graphic novels, Scott Pilgrim does not have a darker tone and does not use

041 swear-words. In 2010, the movie adaptation of the graphic novel was made, and it is called Scott Pilgrim vs. The World, directed by Edgar Wright. The movie combined all six series of the graphic novel. Because of that, the movie translated the unique intrinsic elements used in graphic novels into the movies, which can be difficult for people watching to understand what is happening in the movie. Ramrao (2016) stated that film and literature are two different things. According to Ramrao, literature uses the written aspect of communication, whether in poetic, dramatic, or fiction form while film uses the spoken aspect of communication. Ramrao stated that the difference between films and literature is the visual images that stimulate our perception differently. In literature, we must use our imagination to build the world of the story, while films built the world for us. However, Cruz (2014) stated that both have the main similarity: to tell a story, they also share similar genres, such as romantic, horror, science fiction, and adventure.

Albeit different, Ramrao noted that many kinds of literature had been adapted into films since the beginning of films, either from novels, poems, dramas, or short stories, for example, Frankenstein, Dracula, Cinderella, and so on. Although adapted, many films are not similar to their primary source because Leitch (2007) noted that changes are inevitable when literature works moves into a visual medium. Thus the success of movie adaptation depends on the skills and creativity of the movie directors and writers to 'translate' the literature into movie, according to Ramrao. Ramrao furthermore noted that even though literature and film are two different things, one thing is evident that both of them give literacy. Literature gives verbal literacy while film gives visual literacy, hence why the film can be considered literature, thus sharing literature elements into films, such as the intrinsic elements.

According to Eagleton (1996), Intrinsic elements are the elements that made literature from within, intrinsic elements consist of Plot, Characters, Setting, and Theme. 
Klarer (2004) stated that a plot is the logical interaction of various elements that leads to a change of the original situation into the outset of the narrative. According to Bordwell and Thompson (2014), the plot is used to describe everything visibly and Character, Setting, audibly present in the movie. The plot includes all the story events directly depicted and may contain material extraneous to the story. Diyanni (2000) explained that plots are usually consisting of five main elements, such as exposition, rising action, climax, falling action, and resolution. Exposition is the opening/beginning of the story, which introduces the characters, setting, and background information of the story, so the audience could understand and follow the movie. The rising action is the part of the story in which the conflict of the movie occurs. Usually, there are two conflicts faced by the main characters; internal and external conflicts. The climax is when the main character must face the greatest conflict (Diyanni, 2000). The climax is the peak of the movie, usually features the culminating conflicts and struggles the main character has had throughout the movie. The falling action is when the tension of the story calms down (Diyanni, 2000). Resolution (Denouement) is when the conflicts of the movie are resolved (Diyanni, 2000).

According to Russel (2010), there are four types of plot structure: Dramatic plot, which establishes the setting and conflict first, then followed with rising action through climax until the end of the movie. An Episodic plot is made up of a series of stories linked together by the same character, place, or theme, but is separated by their plot, purpose, and subtext. A parallel plot is where the main characters have a separate but related storyline that merged in the end. Meanwhile, flashback gives information about events that happened before the current point of the story. It lets the story begin in the middle of the action, but later it fills in the story needed to allow the audience to fully understand what happened before the current story happens (the backstory). There are two types of flashbacks, those who recall events that happened before the story (external flashbacks) and those that recount events that already happened in the movie (internal flashback).

\section{Characters}

According to Russell (2010), characters can be divided into three types: The protagonist is the central figure of the movies. Usually, the main character in the movie is the protagonist. An antagonist, the figure who opposes the protagonist and creates a conflict is usually the evil character in the movie. The next one is the foil characters, the 
Intrinsic

Elements, figure with different personality traits from the main character's. Usually, the supporting

Plot,

Character,

Setting, characters in the movie and help the main character to shine. Russell also stated there are Theme two ways the characters are portrayed: Flat characters do not have depth and no change, mostly portrayed by supporting characters, for example, an evil stepmom, lousy neighbor,

043 selfish friend, and so on. Round/dynamic characters have more developed personalities. Mostly portrayed by the protagonist and the antagonist of the movie, who expresses a range of emotion and change throughout the movie.

\section{Setting}

Gill (1995) stated that setting covers the places the characters appear, the social context of characters, the particular locations of events, and the atmosphere the movie creates. Russell (2010) mentioned there are two types of setting: Integral setting, when the place and time influence the theme, characters, and action of a movie. and backdrop setting, a vague and general setting, helps to convey a universal, timeless tale.

\section{Theme}

Russell (2010) said that theme is the main idea of literature. A theme is invented into the story subtly rather than being told by the narrator/author. A theme is the general idea of the movie; a theme is also the message the filmmakers want to share in their movie. In this modern age of cinema, the most common themes used for movies are love, good vs. evil, humanity vs. technology, and so forth.

Based on the theories above, this study is going to explain what intrinsic elements are used in the movie Scott Pilgrim vs. The World and how the intrinsic elements are intertwined with each other in the movie. This study is done as there are few to no other studies explaining the intrinsic elements used in the movie Scott Pilgrim vs. The World.

\section{METHODS}

\section{Research Design}

This study used a qualitative research approach to obtain the data needed that is in line with the objectives (Leavy, 2017). This study explained the intrinsic elements used 
in the movie Scott Pilgrim vs. The World, which was used as the source of the data, and Elements,

to find out whether the intrinsic elements were related to each other.

Plot,

\section{Data Collection}

Character,

Setting,

The data collection was conducted by gathering the audiovisual materials in the

form of utterances, dialogues, and narration of the movie Scott Pilgrim vs. The Movie.

The data came in the form of screenshots to provide the information to answer the research questions (Cresswell, 2013).

\section{Data Analysis}

Once the data were obtained, the author analysed the utterances, dialogues, and narrations from the movie Scott Pilgrim vs. The World. Afterward, the data were presented descriptively to explain the intrinsic elements in literature and how the intrinsic elements could affect each other in literature.

\section{FINDINGS AND DISCUSSION}

\section{Findings}

The author found that the intrinsic elements used in the movie Scott Pilgrim vs. The World consisted of plot, characters, settings, and theme

a. Plot

The author found the plot of Scott Pilgrim vs. the World consist of an exposition, two rising actions, two climaxes, two falling actions, and a resolution

1. Exposition

The story of the movie, told by the narrator, starts in a 'mysterious land' in Toronto, Canada. Scott Pilgrim, the protagonist, is dating a high schooler (min. 00:00:22 - 00:00:31). In the first scene, the movie is telling the story of Scott Pilgrim. It shows how Scott Pilgrim is just an ordinary guy who dates a high schooler as his 'rebound' after his breakup. It also shows his age, job, and girlfriend - Knives Chau - and his friends. (min. 00:01:48 - 00:08:49)

2. Rising action

The first rising action starts when Scott has an 'idiotic' dream about a girl (min. 00:10:08 - 00:10-29), which turned out to be real (min 00:11:17). He finds out about 


\section{Intrinsic}

Elements,

Plot,

Character,

Setting,

Theme her name, Ramona Flowers, at a party he goes to in which someone told him to stay away from Ramona (min. 00:12:05 - 00:15:00). Scott, now is crazy about Ramona, totally forgets about Knives (min. 00:17:35) and is now confused on how to break up with her (min. 00:18:00 - 00:18:36). Although he is still with Knives, Scott asked Ramona on a date (00:21:09). Scott made himself in a love triangle between him and Ramona and Knives. Unbeknownst to him, Ramona's love life is under the control of her seven evil exes, and he has to fight the first ex, Matthew Patel, during his band's performance (00:30:55 - 00:35:35).

After the fight, Ramona explained that to become her boyfriend, Scott must defeat her seven evil exes (00:36:16). The second rising action starts when Scott is willing to fight to get Ramona back from Gideon (min. 1:29:22)

3. Climax

The first climax in this movie is after Scott's fight against Ramona's fourth ex, Roxy. After the fight, Scott feels tired of fighting Ramona's exes that he argues with her until she said they need to split up (min. 1:18:04 - 1:19:09). The movie has the second climax when Scott is fighting Ramona's last ex, in which he must choose to fight for love or his self-respect (min. 1:30:03 - 1:45:00).

4. Falling action

The first falling action happens when Ramona choose Gideon over Scott (min. 1:25:09 - 1:28:45). The second falling action happens when Scott defeated Gideon and apologizes to Knives and Ramona for his bad behavior towards both of them (min. 1:44:07)

5. Resolution

Resolution in the movie happens towards the end of the movie, when Scott chose Ramona over Knives after their battle against Gideon.

b. Characters

The protagonists of Scott Pilgrim vs. The World are Scott Pilgrim and Ramona Flowers. Throughout the film. Scott are characterized as a good guy that was willing to fight for love even though sometimes he became selfish because he chose Ramona over Knives, his current girlfriend. Scott was characterized as a 'player' because he dated a lot of women before he dated Knives (min. 00:15:13 - 00:15:22), which he said was 'mourning period' after his big break up with his ex. Scott had to fight 
Ramona's seven evil exes in order to gain her affection and date her. While Ramona is the main love interest in this movie. She worked at Amazon as delivery girl. She lived in New York but moved to Toronto after her break up with her ex which turned out to be Gideon, the main antagonist. She was secretive about her past at first but Elements, Plot, Character, Setting, then opened up to Scott about her seven evil exes, whom Scott has to fight to date Ramona.

The main antagonist is Gideon Graves. Gideon is the leader and the creator of the League of Evil Exes. In the movie, Gideon only appeared in the last half of the movie, with his name mentioned in the first half as G-Man, and G-Man Greaves. Gideon is also the producer who hosts the tournament where Scott's band took part in. Gideon planted a microchip on the back of Ramona's head to control her.

The supporting characters in the movie are Knives Chau, Wallace Wells, Scott's bandmates: Stephen Stills, Kim Pine, "Young" Neil, Ramona's evil exes: Matthew Patel, Lucas Lee, Todd Ingram, Roxy Ritcher, The Katanayagi Twins, and Envy Adams.

c. Settings

In the movie Scott Pilgrim vs. The World, there are only two settings used in the story; setting of place and setting of time

1. Setting of Place

The story is set mainly in a suburb in Toronto, Canada. Throughout the movie, there are lots of places shown, such as "Young" Neil's house, the place where Scott's band practices, Scott's and Wallace's "Man Lair" 3 concert place: The Rockit, Lee's Palace and Ninth Circle, and Chaos Theater.

\section{Setting of Time}

The movie is set in a "not-so-long ago" as told by the narrator at the beginning of the film. Based on the technology used throughout the movie it was set during the late 2000's, quite close to the release date of the movie (2010). The movie took place during winter, as seen in some scenes where snow was falling from the sky, and the streets were covered in snow.

d. Theme

Due to the plot of the movie is how Scott Pilgrim has to fight Ramona's exes to gain her affection and love, the author found that the general theme used in the movie 


\section{Intrinsic}

Elements,

Plot,

Character,

Setting,

Theme

\section{Discussions}

\section{7}

The findings show that the movie Scott Pilgrim vs. The World used dramatic plot because the movie established the setting and conflicts first and used two rising actions, two climaxes, and two falling actions as the plot points, based on the theory from Russell (2010).

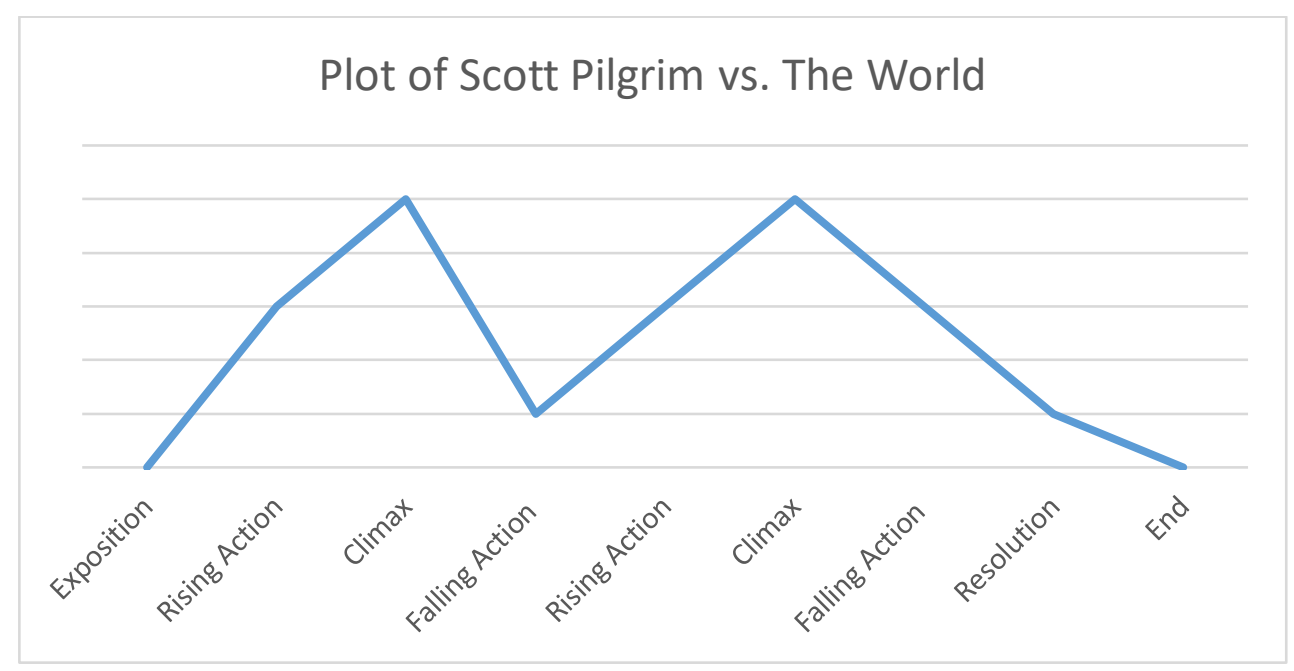

Based on the data and the findings, there are six interrelations between each intrinsic elements used in the movie such as:

\section{Relation Between Plot and Characters}

Character and plot development are connected; each is dependent on each other but at the same time is made possible by each other (Culleton, 2020). Some appearances of characters changed the plot in the movie Scott Pilgrim vs. The World. For example, the appearance of Gideon changes the plot by giving the story another rising action, thus made the movie to have two climaxes in the story. The introduction of Ramona's exes also changed the plot a little by giving them flashbacks, thus revealing Ramona's past and changed her characterization.

\section{Relation Between Plot and Settings}

According to Janovsky (2016), settings have a major impact on what occurs in the plot. Settings can be used to develop the plot. The relation between plot and setting 
started to happen when the plot is rising. The setting of the place changed from Scott's usual places (Young Neil's house and His and Wallace's apartment) to Julie's house party, the place where Scott met Ramona, and to concert place (The Rockit), and the setting of the place changed throughout the movie based on the plot, for example, the Elements, Plot, Character, Setting, club during the first climax, and Chaos Theater during the second climax, also the Ninth Circle during the first falling action and the Chaos Theater during the second Theme falling action.

\section{Relation Between Plot and Theme}

Plot, settings, and character are the factual structure of the theme (Stanton, 1965). Based on the statement, the relation between the plot and theme is the plot dictates the movie's theme. The movie Scott Pilgrim vs. The World is Scott's and Ramona's romantic relationship based on the past relationship. It can be determined that the theme of the movie is romance generally, and unresolved past relationship specifically.

\section{Relation Between Characters and Settings}

The relation between characters and settings happens when a new character is introduced in Scott Pilgrim vs. The World. Ramona's evil exes introductions showed a new setting of place, for instance, the introduction of Mathew Patel moved the setting of place from Scott's apartment into the Rockit, a concert place, and the introduction of Gideon showed the Chaos Theater.

\section{Relation Between Characters and Theme}

Since the theme of the movie Scott Pilgrim vs. The World is an unresolved past relationship, other characters in this movie had a relationship in the past with the main protagonists, either romantically or not. For example, Knives Chau was Scott's exgirlfriend and the main antagonist, Gideon, was Ramona's ex-boyfriend.

\section{Relation Between Settings and Theme}

Mainly set in Toronto, Canada, the setting of place does not correlate with the movie theme. Even though the setting of the place does not correlate with the theme, the setting of time has a little relation with the theme, as winter is the reason the romance between Scott and Ramona started since Ramona invited Scott to her house because it started snowing, thus led to Ramona and Scott's first kiss inside the house. 


\section{Intrinsic}

Elements,

Plot,

Character,

Setting,

Theme

\section{CONCLUSION}

Based on the research, the author drew some conclusions on the movie Scott Pilgrim vs. The World. Scott Pilgrim vs. The World is directed by Edgar Wright. The movie was released in 2010 and has four intrinsic elements included in the movie: plot, characters, setting, and theme. The plot of the movie Scott Pilgrim vs. The World has one exposition, two rising actions, two climaxes, two falling actions, and one resolution. The characters of the movie Scott Pilgrim vs. The World can be divided into two categories: the main characters Scott Pilgrim, Ramona Flowers, and the antagonist Gideon Graves. The supporting characters: Knives Chau, Wallace Wells, Stephen Stills, Kim Pine, and 'Young' Neil, and Ramona's evil exes. The setting of place of the movie is mainly in Toronto, Canada. The setting of time of the movie is during the late 2000's, and takes place during winter time as intercepted based on the snow falling from the sky in some scenes. The plot of the movie is how Scott Pilgrim has to fight Ramona's exes to gain her affection and love. The theme used in the movie Scott Pilgrim vs. The World is romance with unresolved past relationship. The intrinsic elements in the movie also relate to each other with some appearances of some characters changed the plot in the movie. The setting changed when the plot is rising, and the theme of the movie is based on the plot of the movie, which is main protagonists' romantic relationship based on the past relationship.

\section{REFERENCES}

Ardiyanthi, Dewi Pisca. (2010). "The Intrinsic Elements of the House by Dina Oktaviani". State Islamic University Syarif Hidayatullah, Jakarta.

Bertens, H. (2014). Literary Theory: The Basics. New York: Routiledge.

Bordwell, D. and Thompson, K. (2008). Film Art: An Introduction, New York: McGrawHill Companies.

Creswell, John W. (2013). Qualitative, Quantitative and Mixed Methods Approaches, California: SAGE Publications, Inc.

Cruz D.T. (2014). Literature and Film: A Brief Overview of Theory and Criticism in: Postmodern Metanarratives. London: Palgrave Macmillan.

Culleton, T. (2020). "Character and Plot Development." Retrieved July $20^{\text {th }}$ from http://www.fiction-writers-mentor.com/character-and-plot-development/.

Diyanni, R. (2000). Fiction: An Introduction. Singapore: McGraw Hill Higher Education.

Eagleton, T. (1996). Literary Theory: An Introduction. Oxford: Blackwell.

Gavin, A. (2014). Literature and Film, Dispositioned. New York: Palgrave Macmillan. 
Intrinsic

Gill, R. (1995). Mastering English Literature, New York: Palgrave.

Indriani, D. Silli, S. Ariani, S. (2019). "An Analysis of Intrinsic Elements in Mama Film." Departement of English Literature, Faculty of Cultural Study, Mulawarman University.

Elements, Plot,

Character, Setting,

Janovsky, Angela. (10 December 2016.) "How Setting Shapes the Characters \& Plot. Theme Retrieved July $20^{\text {th }}$ from study.com/academy/lesson/how-setting-shapes-thecharacters-plot.

Karim, M. F. (2016). "An Analysis of Intrinsic Elements and Moral Values of "The Swamp" in A.K. Srikumar Novel." English Education Department, Teacher Training and Education Faculty of State Institue of Islamic Study Salatiga.

Klarer, M. (2004). An Introduction to Literary Studies. New York: Routledge.

Leitch, T. (2007) Film Adaptation and Its Discontents: From Gone with the Wind to Passion of the Christ. Baltimore: The John Hopkins University Press.

Leavy, P. (2017). Research Design Quantitative, Qualitative, Mixed Methods, ArtsBased, and Community-Based Participatory Research Approaches. The Guilford Press.

Ramrao, Dr. T. N. (2016). "Film and Literature: An Overview." Department of English, Vivekananda College, India.

Russel, D.L. (2010) Literature for Children: A Short Introduction. New York: Ferris State University.

Setiawati, W. (2016). "The Analysis of Intrinsic Elements in The Little Prince; A Novel by Antoine de Saint Exupery." English Education Program, Faculty of Teacher Training and Education, University of Mataram

Stam, R. and Raengo, A. (2004). A Companion to Literature and Film. Oxford: Blackwell Publishing Ltd.

Stanton, R. (1965). An Introduction of Fiction. New York: Holt, Reinhart, and Winston Inc. 